\title{
Effect of Allium sativum (garlic) methanol extract on viability and apoptosis of human leukemic cell lines
}

\author{
Malina Jasamai, Chee Sze Hui, Norazrina Azmi and Endang Kumolosasi* \\ Drug and Herbal Research Centre, Faculty of Pharmacy, Universiti Kebangsaan Malaysia, Jalan Raja Muda Abdul Aziz, \\ 50300, Kuala Lumpur, Malaysia \\ *For correspondence: Email: e_kumolosasi@yahoo.co.id; Tel: +60392898054; Fax: +60326983271
}

\begin{abstract}
Purpose: To investigate the effect of Allium sativum (garlic) methanol extract on viability and apoptosis of human leukemic cells.

Methods: Cell viability was determined using 3-(4,5-dimethylthiazol-2-yl)-2,5-diphenyltetrazolium bromide (MTT) assay at concentrations of $3.125,6.25,12.5,25,50,100,200,400$ and $800 \mathrm{ug} / \mathrm{mL}$ of Allium sativum extract following 48-h treatment on U-937, Jurkat Clone E6-1 and K-562 cell lines. The mode of cell death was determined by Annexin V-FITC staining and analyzed by flow cytometry.

Results: The results show that the half-maximal inhibitory concentration $\left(I C_{50}\right)$ of A. sativum on U-937, Jurkat Clone E6-1, K-562 cell lines was $105 \pm 2.21,489 \pm 4.51$ and $455 \pm 3.13 \mu \mathrm{g} / \mathrm{mL}$, respectively, compared with negative control, while apoptosis was $17.93 \pm 0.95 \%$ for U-937 cells $(p \leq 0.05), 38.37 \pm$ $1.88 \%$ for Jurkat Clone E6-1 cells ( $p \leq 0.001)$ and $16.37 \pm 1.10 \%$ for K-562 cells. A majority of the cells were inhibited by the extract via apoptosis. Only U-937 cells (6.87 $\pm 0.65 \%)$ showed significant necrosis compared to negative control $(p \leq 0.05)$.

Conclusion: $K-562$ cells are the most resistant against garlic extract, in contrast to Jurkat Clone E6-1 cells. Garlic extract does not induce necrosis in Jurkat Clone E6-1 and K-562 cells.
\end{abstract}

Keywords: Anti-leukemic, Garlic, Allium sativum, Annexin V-FITC staining, Necrosis, Apoptosis, Flow cytometry, Jurkat Clone E6-1 cells

Tropical Journal of Pharmaceutical Research is indexed by Science Citation Index (SciSearch), Scopus, International Pharmaceutical Abstract, Chemical Abstracts, Embase, Index Copernicus, EBSCO, African Index Medicus, JournalSeek, Journal Citation Reports/Science Edition, Directory of Open Access Journals (DOAJ), African Journal Online, Bioline International, Open-J-Gate and Pharmacy Abstracts

\section{INTRODUCTION}

Each year there are about 351000 new cases of leukemia worldwide which represent $2.8 \%$ of all cancers and $3.4 \%$ of deaths from cancer [1]. Although there are various clinical therapies such as bone marrow transplant, radiotherapy and chemotherapy used to treat leukemia patients, most treatments are not yet satisfactory as severe side effects are still observed. So far, the best strategy for killing leukemia cells is through the induction of apoptosis cancer cells [2]. The use of natural agents such as vincristine and vinblastine (Vinca alkaloid) or synthetic compounds may restrict or prevent the development of invasive cancer. Therefore, phytochemicals become an increasingly important source since they have the potential to inhibit tumor formation at all levels [3].

Allium sativum, also known as garlic, plays an important role in the reduction of the prevalence of cancer [4]. It has various pharmacological activities including antimicrobial, antihyperlipidemic, antithrombotic and anticancer effects [5]. Garlic and its organic allyl sulfur components such as diallyl sulfide (DAS), diallyl disulfide (DADS) and diallyl trisulfide (DATS) can inhibit 
carcinogenesis process and effectively reduce chemotherapeutic toxicities [6]. Choi and Park, [5] showed that DATS-induced apoptosis was correlated with down-regulation of Bcl-2, XIAP, and clAP-1 protein levels, cleavage of Bid proteins, activation of caspases, and collapse of mitochondrial membrane potential. Furthermore the cytotoxicity effect caused by DATS is mediated by generation of ROS and subsequent activation of the ROS-dependent caspase pathway in U937 leukemia cells. Even though some studies for the active compounds of $A$. sativum has been carried out, the effect of the extract on leukemic cells was not well established.

The objective of this study was to determine the effects of garlic methanolic extract on viability and apoptosis of human leukemic cell lines; $U$ 937, Jurkat Clone E6-1 and K-562 cells.

\section{EXPERIMENTAL}

\section{Chemicals and reagents}

Chemicals used in this study included GibcoTM Roswell Park Memorial Institute (RPMI) Medium 1640 (Life Technologies, USA), GibcoTM Iscove's Modified Dulbecco's Medium (IMDM) (Life Technologies, USA), GibcoTM Fetal Bovine Serum (FBS) (Life Technologies, USA), Penicillin Streptomycin Antibiotic (Amresco, USA), trypan blue solution $0.4 \%$ (Sigma-Aldrich, USA), thiazolyl blue tetrazolium bromide methyl thiazolyldiphenyl-tetrazolium bromide (MTT) reagent powder (Sigma-Aldrich, USA). GibcoTM Synth-a-Freeze ${ }^{\circledR}$ cryopreservation medium (Life Technologies, USA) and Annexin V-FITC apoptosis detection kit (Sigma-Aldrich, USA).

\section{Plant material and extraction}

Allium sativum (AS), (herbarium voucher number: UKM-B 30093), was purchased from Kuala Lumpur, Malaysia and then dried at room temperature $\left(30{ }^{\circ} \mathrm{C}\right)$. In the extraction process, the dried AS was milled into coarse powder using a mechanical grinder then maceration was carried out by soaking the AS in $99.5 \%$ methanol with a ratio of 1:5 for three days at room temperature with occasional shaking. After the extraction was completed, filtration was carried out and the filtrate was concentrated using rotatory evaporator at $40{ }^{\circ} \mathrm{C}$ to yield methanol extract of AS. The residue was macerated twice. Lastly, the AS extracts were kept in a refrigerator at $4{ }^{\circ} \mathrm{C}$ throughout the study.

\section{Cell cultures}

U-937 human leukemic monocyte lymphoma cell line with catalog number ATCC $®$ CRL-1593.2 ${ }^{\mathrm{TM}}$, Jurkat, Clone E6-1 human acute T cell leukemia cell line and K-562 human chronic myelogenous leukemia cell line with catalog number of ATCC® TIB-152 ${ }^{\mathrm{TM}}$ and ATCC $\AA$ CCL-243 ${ }^{\mathrm{TM}}$ respectively were purchased from the American Type Culture Collection (ATCC), USA. Both U-937 and Jurkat Clone E6-1 cells were cultured in the complete RPMI 1640 media while K-562 cells were cultured in the complete IMDM with an addition of $50 \mathrm{~mL}$ fetal bovine serum and $5 \mathrm{~mL} 100 \mathrm{X}$ Penicillin Streptomycin. The cells were incubated in a high humidity (95\%) atmosphere at a temperature of $37^{\circ} \mathrm{C}$ and $5 \% \mathrm{CO}_{2}$.

\section{MTT assay}

After the cells were treated with AS extract for 48 hours, $20 \mu \mathrm{L}$ of MTT solution was added into each well. The MTT assay procedure was performed as described by Wang et al and Scherlie [7,8]. Then, the 96 well plates were incubated for $4 \mathrm{~h}$ at $37^{\circ} \mathrm{C}$ and $5 \% \mathrm{CO}_{2}$. After 4 hours incubation, $150 \mu \mathrm{L}$ of media in all the wells were removed and $150 \mu \mathrm{L}$ of dimethyl sulfoxide (DMSO) was added then incubated further for 10 min. Absorbance at $565 \mathrm{~nm}$ was read using a microplate reader (Infinite ${ }^{\circledR} 200$ Pro, Tecan, Switzerland) [9]. Cell viability was calculated as in Eq1.

Cell viability $(\%)=\{(\mathrm{At}-\mathrm{Ab}) /(\mathrm{Ac}-\mathrm{Ab})\} 100 \ldots$

where At, $A b$ and $A c$ are the absorbance of treated, blank and negative control samples, respectively. A graph of cell viability (\%) versus concentration of treatment solution was plotted and $\mathrm{IC}_{50}$ was determined from the graph.

\section{Apoptotic assay}

Annexin V FITC staining was carried out to determine the mode of cell death for U-937, Jurkat Clone E6-1 and K-562 cells after treatment with the AS extract. Staining for apoptotic determination was performed as described by Hodge et al and Vermes et al $[10,11]$. A total of $2 \mathrm{~mL}$ of cell suspension was seeded in each well of the 6 well plate at a concentration of $5 \times 10^{5}$ cells $/ \mathrm{mL}$ and were treated with extract at concentrations of 200 $\mu \mathrm{g} / \mathrm{mL}$ and $40 \mu \mathrm{L}$ of serum free media was added to the wells then mixed uniformly. Next, the cell morphology was observed under an inverted microscope and the 6 well plate was incubated in $\mathrm{CO}_{2}$ for $48 \mathrm{~h}$. After incubation, the cells were stained using Annexin V-FITC and $10 \mu \mathrm{L}$ of 50 
$\mu \mathrm{g} / \mathrm{mL}$ propidium iodide solution was added and homogenized. Lastly, the mode of cell death was analyzed using flow cytometry, model BD FACSCanto II (BD Biosciences, US) [12].

\section{Statistical analysis}

GraphPad Prism 5 was used to analyze the data obtained. Cell inhibition data from MTT assay, and apoptotic and necrotic cells in Annexin $V$ FITC staining are expressed as mean \pm standard error mean (SEM, $n=3$ ). One-way ANOVA with Tukey's Post Hoc test was used to test significant difference with significant level set at $p$ $\leq 0.05$.

\section{RESULTS}

\section{Effect of garlic extract on U-937, Jurkat Clone E6-1 and K-562 cell lines}

After exposure to garlic extract for 48 hours, percentage inhibition of viability of U-937 cells increased at increasing concentration. Referring to Figure 1, percentage of cell viability inhibition at concentration $50 \mu \mathrm{g} / \mathrm{mL}$ was $34.08 \pm 7.11 \%$ and result showed significant difference ( $p \leq$ 0.01) as compared to negative control. At concentrations $100 \mu \mathrm{g} / \mathrm{mL}, 200 \mu \mathrm{g} / \mathrm{mL}, 400$ $\mu \mathrm{g} / \mathrm{mL}$ and $800 \mu \mathrm{g} / \mathrm{mL}$, the percentage of cell viability inhibition increased as concentration increased, those were $49.3 \pm 3.51,64.9 \pm 9.81$, $78.39 \pm 1.38$ and $93.29 \pm 1.98 \%$. The increasing percentage of cell inhibition was significantly different ( $p \leq 0.001$ ) when compared with the negative control. Table 1 showed that the $\mathrm{IC}_{50}$ of garlic extract on U-937 cells was $105.00 \pm 2.21$

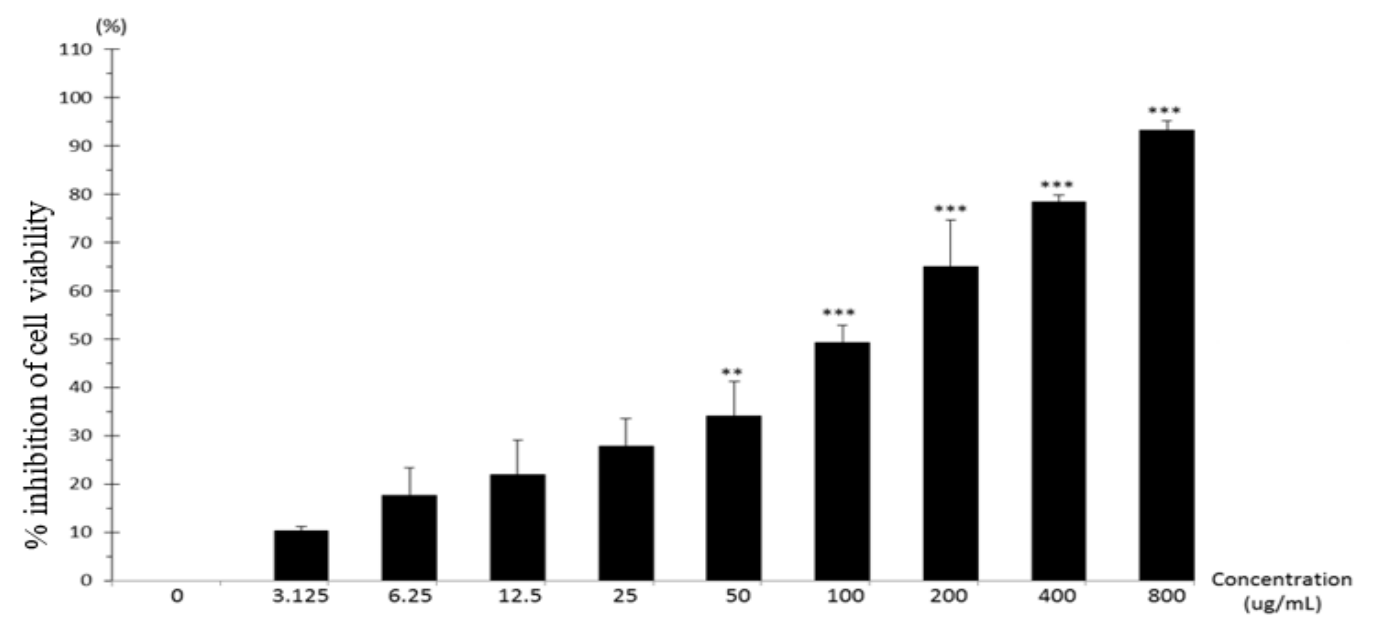

Figure 1: Inhibition of U-937 cell viability treated with garlic extract at increasing concentration. All the columns show the mean \pm SEM $(n=3)$; ${ }^{* *}$ statistically significant difference with negative control $(0 \mu \mathrm{g} / \mathrm{mL}, p \leq 0.01) ;{ }^{* * *}$ significantly different from negative control $(0 \mu \mathrm{g} / \mathrm{mL}, p \leq 0.001)$ $\mu \mathrm{g} / \mathrm{mL}$. The cell viability inhibition presented in a concentration-dependent manner.

Viability of Jurkat Clone E6-1 cell line was reduced as concentration increased. Referring to Figure 2, percentage of cell viability inhibition at concentration 50 and $100 \mu \mathrm{g} / \mathrm{mL}$ were $13.53 \pm$ 1.69 and $15.34 \pm 0.86 \%$, respectively. The percentage of cell viability inhibition was significantly different $(p \leq 0.01)$ as compared with negative control. At concentrations 200, 400 and $800 \mu \mathrm{g} / \mathrm{mL}$, the percentage of cell viability inhibition were $18.72 \pm 1.97,43.55 \pm 4.37$ and $73.15 \pm 2.97 \%$. The increased percentage inhibition of cell viability showed significant difference ( $p \leq 0.001$ ) as compared with the negative control. Table 1 showed that the $I_{50}$ of garlic extract on Jurkat Clone E6-1 cells was 489 $\pm 4.51 \mu \mathrm{g} / \mathrm{mL}$. The cell viability inhibition presented in a concentration-dependent manner.

The same pattern with reduced percentage of viability of K562 cell line was observed as concentration increased. Referring to Figure 3, percentage of cell viability inhibition at concentration $100 \mu \mathrm{g} / \mathrm{mL}$ was $22.7 \pm 3.97 \%$ and the result showed a significant difference $(p \leq$ 0.01 ) as compared to the negative control. At concentration 200, 400 and $800 \mu \mathrm{g} / \mathrm{mL}$, the percentage of cell viability inhibition were $23.06 \pm$ $4.33,45.9 \pm 4.48$ and $69.26 \pm 4.71 \%$. The increased percentage of cell inhibition showed a significant difference ( $p \leq 0.001$ ) as compared with the negative control. Table 1 showed that the $\mathrm{IC}_{50}$ of garlic extract on Jurkat Clone E6-1 cells was $455 \pm 3.13 \mu \mathrm{g} / \mathrm{mL}$. The inhibition of cell viability was in a concentration-dependent manner. 


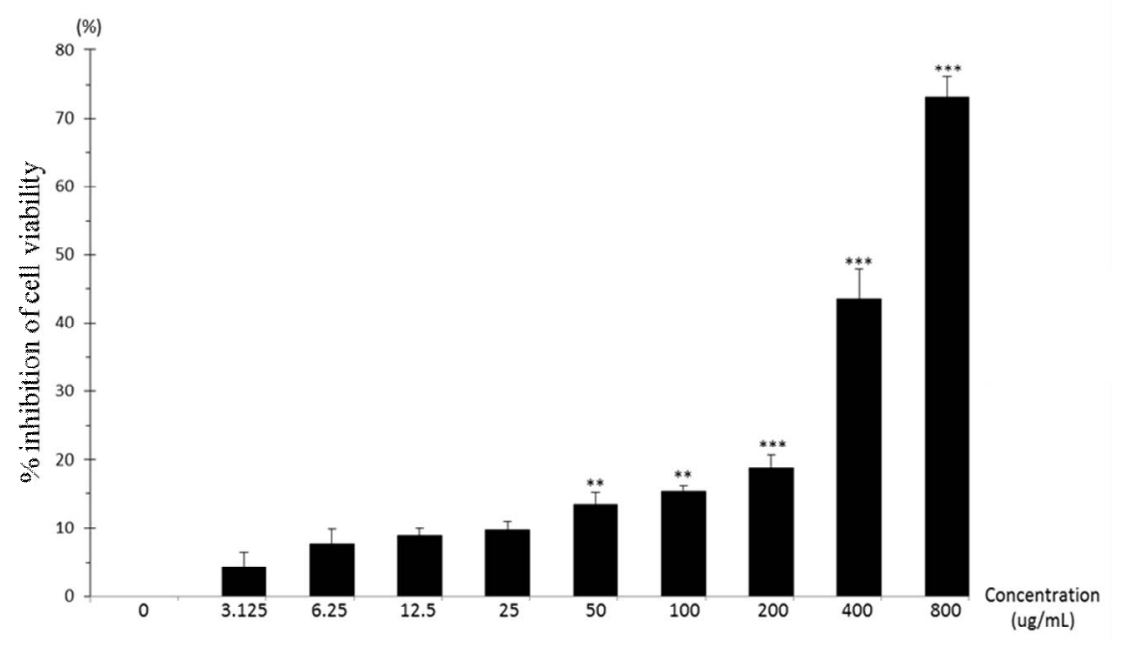

Figure 2: Inhibition of Jurkat Clone E6-1 cell viability treated with garlic extract at increasing concentration. All the columns show the mean \pm SEM for 3 independent experiments $(n=3)$. ${ }^{*}$ Statistically significant difference with negative control $(0 \mu \mathrm{g} / \mathrm{mL}) p \leq 0.01$; ${ }^{* *}$ Statistically significant difference with negative control $(0 \mu \mathrm{g} / \mathrm{mL})$ $p \leq 0.001$

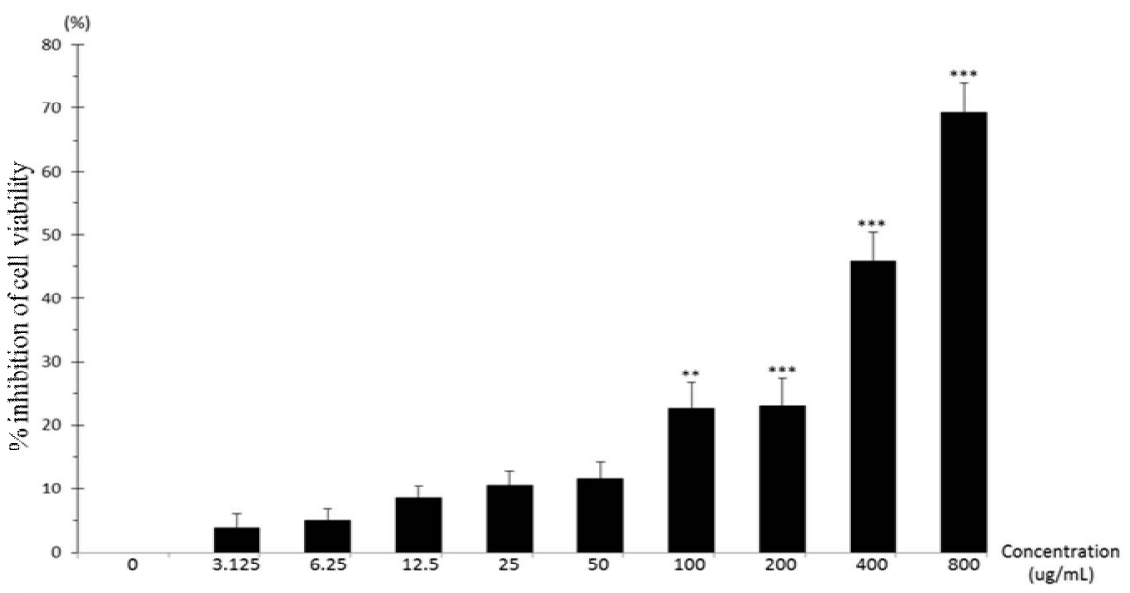

Figure 3: Inhibition of K-562 cell viability treated with garlic extract at increasing concentration. All the columns show the mean \pm SEM $(n=3) ;{ }^{* *}$ significantly different from negative control $(p \leq 0.01) ;{ }^{* *}$ significant different from negative control $p \leq 0.001$.

Table 1: $\mathrm{IC}_{50}$ of garlic extract on U-937, Jurkat Clone E6-1 and K-562 cells

\begin{tabular}{lc}
\hline Cell line & $\mathbf{I C}_{50}(\mu \mathbf{g} / \mathbf{m L})$ \\
\hline U-937 & $105 \pm 2.21$ \\
Jurkat Clone E6-1 & $489 \pm 4.51$ \\
K-562 & $455 \pm 3.13$ \\
\hline
\end{tabular}

Mode of cell death of U-937, Jurkat Clone E61 and K-562 cell lines

The mode of cell death was measured in Annexin $V$ FITC staining test using flow cytometry. After exposure to $200 \mu \mathrm{g} / \mathrm{mL}$ of garlic extract for 48 hours, most of the inhibition of $U$ 937 cell line underwent apoptosis. Referring to Table 2, $17.93 \pm 0.95 \%$ of cells underwent apoptosis whereas $6.87 \pm 0.65 \%$ of cells underwent necrosis. The result was significantly different ( $p \leq 0.05$ ) when compared with the negative control.

After exposure to $200 \mu \mathrm{g} / \mathrm{mL}$ of garlic extract for $48 \mathrm{~h}$, most of the inhibition of Jurkat Clone E6-1 cell line underwent apoptosis as well. Table 2 showed $38.37 \pm 1.88 \%$ of cells that underwent apoptosis was significantly different $(p \leq 0.001)$ 
when compared to negative control and not significantly different when compared to the negative control for the number of necrotic cells $(4.23 \pm 0.12 \%)$ induced by AS extract.

Referring to Table 2, after exposure to 200 $\mu \mathrm{g} / \mathrm{mL}$ of garlic extract for $48 \mathrm{~h}$, majority of K-562 cell line decreased in viability non-significantly compared to the negative control. The number of cells which underwent apoptosis (16.37 \pm 1.10 $\%)$ and necrosis $(1.13 \pm 0.33 \%)$ were also not significant compared with negative control $(12.13$ $\pm 0.72 \%)$ and $(0.93 \pm 0.15 \%)$ respectively.

Table 2: Viable, apoptotic and necrotic cells treated with garlic extract at a concentration of $200 \mu \mathrm{g} / \mathrm{mL}$

\begin{tabular}{llccc}
\hline Cell line & Treatment & $\begin{array}{c}\text { Viable cells, Q3(\%, } \\
\mathbf{\pm} \text { SEM) }\end{array}$ & $\begin{array}{c}\text { Apoptotic cells, Q2+Q4 } \\
(\%, \pm \text { SEM) }\end{array}$ & $\begin{array}{c}\text { Necrotic cells, } \\
\mathbf{Q} 1(\%, \pm \text { SEM) }\end{array}$ \\
\hline U937 & Negative control & $90.90 \pm 0.42$ & $6.87 \pm 0.28$ & $2.27 \pm 0.29$ \\
& Garlic extract & $77.80 \pm 1.29^{\text {m }}$ & $17.93 \pm 0.95$ & $6.87 \pm 0.65$ \\
Jurkat & Negative control & $78.33 \pm 1.84$ & $19.30 \pm 2.00$ & $2.37 \pm 0.22$ \\
Clone E6- & Garlic extract & $57.40 \pm 1.86^{\star \pi \times}$ & $38.37 \pm 1.88^{\star \pi \times}$ & $4.23 \pm 0.12$ \\
1 & & & & \\
K562 & Negative control & $86.87 \pm 0.78$ & $12.13 \pm 0.72$ & $0.93 \pm 0.15$ \\
& Garlic extract & $82.5 \pm 1.43$ & $16.37 \pm 1.10$ & $1.13 \pm 0.33$ \\
\hline
\end{tabular}

Data are mean \pm SEM $(\mathrm{n}=3) ;{ }^{*}$ statistically significant difference from negative control $(p \leq 0.05) ;{ }^{* * *}$ significant different from negative control $(p \leq 0.001)$
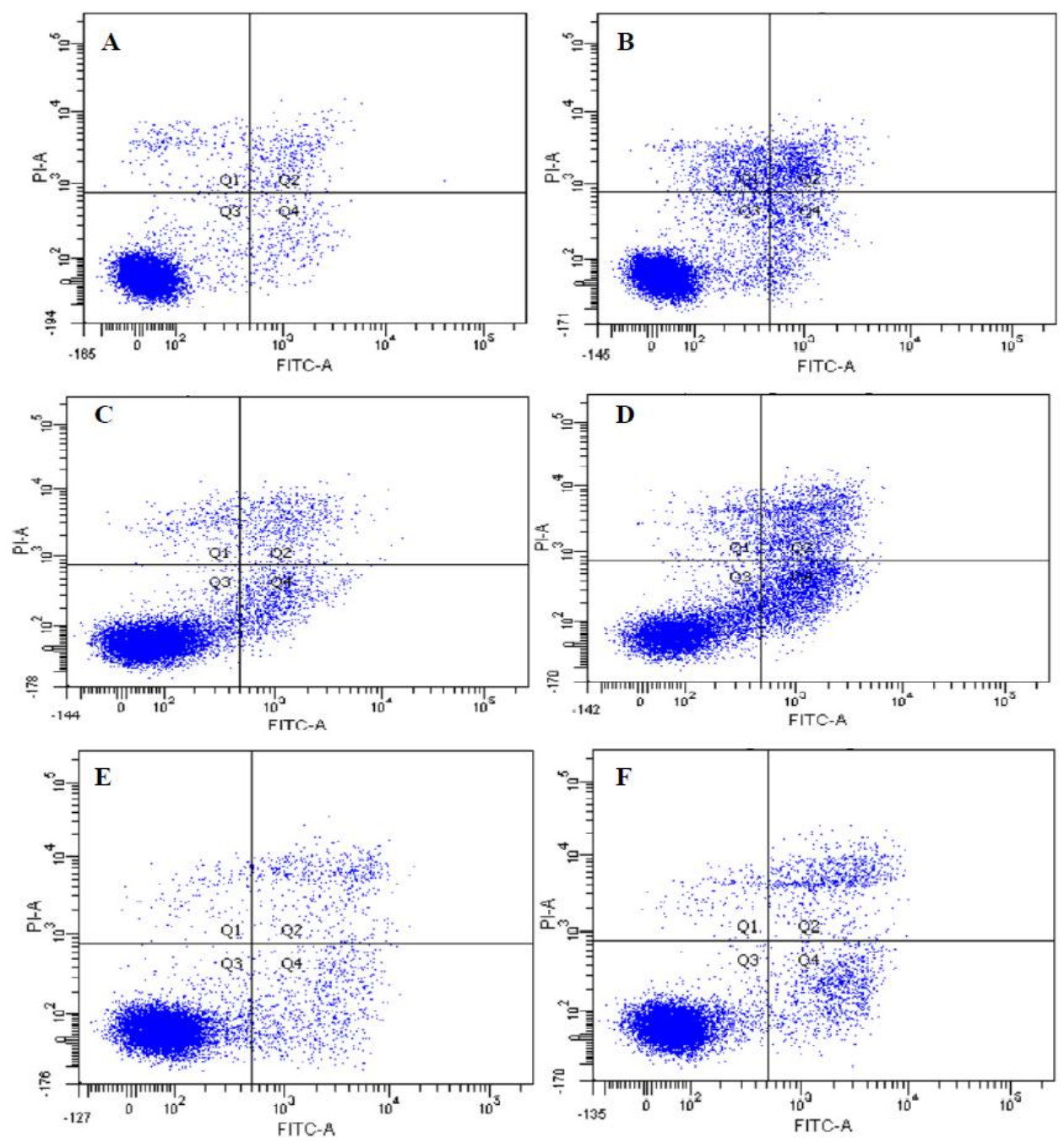

Figure 4: The trend and percentage of viable cells (Q3), early apoptotic cells (Q4), late apoptotic cells (Q2) and necrotic cells (Q1) on U937 (A and B), Jurkat Clone E6-1 (C and D) and K562 (E and F) cells either untreated (A, $C$ and $E)$ or treated with garlic extracts $(B, D$ and $F)$ 


\section{DISCUSSION}

Chemoprevention refers to the use of non-toxic chemical substances to inhibit, delay or reverse cellular events associated with carcinogenesis is regarded as a promising alternative strategy to therapy for the management of cancer [13]. Thus, AS extract as used in this study to test for apoptotic activity on human leukemic cell lines.

From this study, results showed that garlic extract produced in a concentration dependent manner a decrease in the optical density of U937, Jurkat Clone E6-1 and K-562 cell lines in MTT assay. Some studies also showed that DATS in garlic extract induced a decrease in cell viability in a dose- and time-dependent manner in HL-60, U-937, THP-1 and K-562 cells. U-937 cells treated with $20 \mu \mathrm{M}$ DATS for 24 and $48 \mathrm{~h}$ resulted in $53 \%$ and $62 \%$ inhibition respectively which was associated with many morphological changes [5]. The major physiological role of garlic are its antimicrobial, anticancer, antioxidant, immune boosting, antidiabetic, hepatoprotective, antifibrinolytic and antiplatelet activities and its potential role in preventing cardiovascular diseases [14]. Ajoene which is a chemical compound available in garlic is an allylic disulfide originally isolated from garlic extract has been shown to induce apoptosis in human leukemia cell lines [15]. Apart from that, Hassan [16] stated that ajoene can inhibit proliferation and induce apoptosis of several leukemia cells including HL-60, U-937, HEL and OCIM-1. Thus, from our study, the results showed that garlic extract inhibited the cell viability of U-937, Jurkat Clone E6-1 and K-562 cells in a concentration dependent manner and was able to induce apoptosis in these cell lines.

According to Herman-Antosiewicz and Shivendra [17], apoptosis is a tightly regulated process of cellular suicide which is implicated in development, tissue homeostasis and pathological conditions. The two major pathways mediating drug-induced apoptosis are initiated either from internal events within the cells' mitochondria without the involvement of a receptor ligand system which is also known as the intrinsic pathway or at the cell surface of death receptor that is also known as the extrinsic pathway $[15,17]$. From this study, garlic extract mainly induced apoptosis in the human leukemic cell lines such as U-937 cells and Jurkat Clone E6-1 cells. Thus, based on Dirsch et al [15], the organosulfur compound, ajoene, is a promising experimental anti-leukemic agent since it selectively induces apoptosis in human promyeloleukemic cells. Furthermore, Ghosh et al [13] also stated that apoptosis has recently become a useful target in the management and therapy of cancer. From this study, all the leukemic cell lines tested mainly underwent apoptosis rather than necrosis, which implies that the AS extract may have a potential to act as a chemo-preventive agent in leukemic cells.

According to Ritesh and Sanmati [18]. MTT assay is a well-established in vitro method for cytotoxicity against cancer and non-cancer cell lines. From this study, it was utilized to determine the selective activity of the extract. The cells were exposed to the different dilutions of the extract and their $I_{50}$ values were determined. From Ritesh and Sanmati [18], cytotoxic screening models provide important preliminary data to help in selecting potential antineoplastic properties from plant extracts for future work and it is of interest that the extracts of plants show cytotoxicity against cancer cell lines. In this study, the garlic extract showed cytotoxic effects to all the human leukemic cell lines tested and $\mathrm{IC}_{50}$ values were obtained for all the cell lines.

Wu et al [19] stated that the chemopreventive effects of garlic constituents are due to the enhancement of the activity of specified mixedfunction oxidases that depress the activation of carcinogens. Induction of phase II enzymes will enhance detoxification and excretion of potential carcinogens and reduction of the formation of DNA adducts is one the chemopreventive mechanisms for garlic constituents. Furthermore, garlic constituents also can increase the synthesis of glutathione, an endogenous tripeptide thiol that directly protects the cells from damage by free radicals and lastly garlic constituents can induce apoptosis [19].

\section{CONCLUSION}

Garlic extract has the potential to inhibit the cell viability of U-937, Jurkat Clone E6-1 and K-562 cell lines. K-562 cells are the most resistant against garlic extract in contrast to Jurkat Clone E6-1 cells. Garlic extract does not induce necrosis in Jurkat Clone E6-1 and K-562 cells.

\section{DECLARATIONS}

\section{Acknowledgement}

This study was supported by Ministry of Science, Technology and Innovation of Malaysia with grant no. 06-01-02-SF1053.

\section{Conflict of Interest}

No conflict of interest associated with this work. 


\section{Contribution of Authors}

The authors declare that this work was done by the authors named in this article and all liabilities pertaining to claims relating to the content of this article will be borne by them.

\section{REFERENCES}

1. Rosilio C, Sahra IB, Frédéric B, Peyron JF. Metformin: A metabolic disruptor and anti-diabetic drug to target human leukemia. Cancer Lett 2014; 346(2): 188-196.

2. Wen YF, Yang JS, Kuo SC, Hwang CS, Chung JG, Wue $H C$, Huang WW, Jhan JH, Lin CM, Chen HJ. Investigation of anti-leukemia molecular mechanism of ITR-284, a carboxamide analog, in leukemia cells and its effects in WEHI-3 leukemia mice. Biochem Pharmacol 2010; 79: 389-398.

3. Renata N.; Marta O.; Natalia N. Plant Polyphenols as Chemopreventive Agents. In: Watson RR; Preedy Vr.; Zibadi S., editors. Polyphenols in Human Health and Disease, 1st ed., Academic Press; 2014, p.1289-1307.

4. Yi L, Su Q. Molecular mechanisms for the anti-cancer effects of diallyl disulfide. Food Chem Toxicol 2013; 57: 362-370.

5. Choi YH, Park HS. Apoptosis induction of U937 human leukemia cells by diallyl trisulfide induces through generation of reactive oxygen species. J Biomed Sci 2012; 19: 50-61.

6. Ranjani R, Ayya Raju M. Anticancer Properties of Allium sativum $-A$ Review. Asian J Biochem Pharmac Res 2012; 2 (3): 2231-2560.

7. Wang $H$, Cheng $H$, Wang $F$, Wei $D$, Wang $X$. An improved 3-(4,5-dimethylthiazol-2-yl)-2,5-diphenyl tetrazolium bromide (MTT) reduction assay for evaluating the viability of Escherichia coli cells. J Microbiol Meth 2010; 82: 330-333.

8. Scherlie R. The MTT assay as tool to evaluate and compare excipient toxicity in vitro on respiratory epithelial cells. Int J Pharm 2011; 411(1-2): 98-105.

9. Mosmann T. Rapid colorimetry assay for cellular growth and survival: application to proliferation and cytotoxicity assay. J Immunol Methods 1983; 65(1-2): 55-63.
10. Hodge GL, Flower L, Han P. Optimal storage conditions for preserving granulocyte viability as monitored by annexin $V$ binding in whole blood. $J$ Immunol Methods 1999; 225(1-2): 27-38.

11. Vermes I, Haanen C, Steffens-Nakken $H$, Reutellingsperger C. A novel assay for apoptosis flow cytometric detection of phosphotidylserine expression on early apoptotic cells using fluorescein labelled annexin V. J Immunol Methods 1995; 184(1): 39-51.

12. Carlo R, Ildo N. Analysis of apoptosis by propidium iodide staining and flow cytometry. Nat. Protoc 2006; 3: 14581461.

13. Ghosh P, Besra SE, Tripathi G, Mitra S, Vedasiromoni JR. Cytotoxic and apoptogenic effect of tea (Camellia Sinensis var. assamica) root extract (TRE) and two of its steroidal saponins TS1 and TS2 on human leukemic cell lines K562 and U937 and on cells of CML and ALL patients. Leukemia Res 2006; 30: 459-468.

14. Santhosha SG, Jamuna P, Prabhavathi SN. Bioactive components of garlic and their physiological role in health maintenance: A review. Food Biosci 2013; 3: 5974.

15. Dirsch DM, Antlsperger DSM, Hentze H, Vollmar AM. Ajoene, an experimental anti-leukemic drug: mechanism of cell death. Leukemia 2002; 16: 74-83.

16. Hassan HT. Ajoene (natural garlic compound): a new anti-leukaemia agent for AML therapy. Leukemia Res 2004; 28: 667-671.

17. Herman-Antosiewicz A, Shivendra VS. Signal transduction pathways leading to cell cycle arrest and apoptosis induction in cancer cells by Allium vegetablederived organosulfur compounds: a review. Mutat Res 2004; 555: 121-131.

18. Ritesh J, Sanmati KJ. Screening of in vitro cytotoxic activity of some medicinal plants used traditionally to treat cancer in Chhattisgarh state, India. Asian Pac J Trop Biomed. 2011; S147-S150.

19. Wu X, Kassie F, Mersch-Sundermann V. Induction of apoptosis in tumour cells by naturally occurring sulfur containing compounds. Mutat Res 2005; 589: 81-102. 